\title{
Spatial distribution of suspended particulate wastes at open-water Atlantic salmon and sablefish aquaculture farms in Canada
}

\author{
Lindsay M. Brager1, ${ }^{1}$ Peter J. Cranford ${ }^{1, *}$, Jonathan Grant ${ }^{2}$, Shawn M. C. Robinson ${ }^{3}$ \\ ${ }^{1}$ Fisheries and Oceans Canada, Bedford Institute of Oceanography, 1 Challenger Dr., Dartmouth, Nova Scotia B2Y 4A2, Canada \\ ${ }^{2}$ Department of Oceanography, Dalhousie University, Halifax, Nova Scotia B3H 4J1, Canada \\ ${ }^{3}$ Fisheries and Oceans Canada, St. Andrews Biological Station, 531 Brandy Cove Rd., St. Andrews, New Brunswick E5B 2L9, \\ Canada
}

\begin{abstract}
Finfish aquaculture results in the production of particulate waste products that include uneaten feed and faeces. The impact of these wastes on the suspended particle field at 4 open-water fish farms in Canada was studied using high-resolution in situ particle sensors. Within-pen sampling at a sablefish Anoplopoma fimbria farm in British Columbia provided some evidence of the release of low levels (mean effect $<0.2 \mathrm{mg} \mathrm{l}^{-1}$ ) of waste feed near the surface (1-3 m depth), but no waste signal was detectable in surface waters outside this farm. Enhancement of the particle field was also not apparent in surface waters $(0.5-2 \mathrm{~m}$ depth) within the boundaries of an Atlantic salmon Salmo salar farm in the Bay of Fundy. However, data collected outside 2 adjacent farms indicated periodic, low-level particle enhancement (significant mean effect of $<1.0 \mathrm{mg} \mathrm{l}^{-1} ; \mathrm{p}<0.001$ ) near the surface immediately down-current from the net-pens. Despite the large sample numbers obtained, consistent detection of waste particle enhancement was confounded by the apparently small effect size and natural seston patchiness. These results suggest that any farm-induced effect on the surrounding particle field at the study sites would be highly localized and episodic. Consequently, the potential for enhanced production by co-cultured bivalve filter-feeders at these integrated multi-trophic aquaculture farms is limited by available space close to net-pens and the periodic availability of low levels of suspended particulate fish wastes.
\end{abstract}

KEY WORDS: Aquaculture wastes $\cdot$ Suspended particulate matter $\cdot$ Biomitigation $\cdot$ Integrated multi-trophic aquaculture $\cdot$ Salmo salar $\cdot$ Anoplopoma fimbria

\section{INTRODUCTION}

Atlantic salmon Salmo salar aquaculture has grown into a major international industry in the span of 3 decades. In Canada, annual production increased rapidly from the early 1980s to exceed $100000 \mathrm{t}$ by 2001, making Atlantic salmon the predominant aquaculture species (FAO 2010). Production has subsequently ceased expanding, and farms in the Bay of Fundy (New Brunswick) and along the west coast of Canada (British Columbia) contribute the majority of

${ }^{*}$ Corresponding author: peter.cranford@dfo-mpo.gc.ca farmed salmon production (30 and 67\%, respectively). While Atlantic salmon dominates total finfish aquaculture production, the industry is diversifying into other species. The sablefish Anoplopoma fimbria, also known as black cod, is a deep-water fish that is native to the west coast of Canada and is currently being cultured in British Columbia in floating net-pens previously used to culture salmon.

Open-water aquaculture has generated concerns about possible environmental impacts from discharges of excess feed and faeces, nutrients and therapeutic

() Fisheries and Oceans Canada and J. Grant 2015. Open Access under Creative Commons by Attribution Licence. Use, distribution and reproduction are unrestricted. Authors and original publication must be credited.

Publisher: Inter-Research · www.int-res.com 
chemicals to the marine environment, and potential interactions with wild species (Holmer et al. 2005, Strain \& Hargrave 2005, Mente et al. 2006). The accumulation of material on the seabed is one of the more conspicuous impacts of open-water fish farms, caused by the vertical flux of waste organic matter (fish faeces and waste feed) from net-pens (Strain \& Hargrave 2005). The presence and severity of benthic impacts from organic enrichment depend on a number of factors related to local husbandry and environmental conditions (Holmer et al. 2005). The horizontal flux of particulate matter may also be expected to be enhanced from these same waste products; however, elevated particle concentrations around net-pens have been observed in some studies (Jones \& Iwama 1991, Lefebvre et al. 2000, MacDonald et al. 2011) and not in others (Pridmore \& Rutherford 1992, Buschmann et al. 1996). These apparently contradictory findings suggest that the factors contributing to particulate organic loading and dispersal in the water column are not fully understood.

The finfish aquaculture industry has adopted a number of strategies to assess and manage impacts from particulate waste discharges. Strategies have incorporated the application of dispersal/deposition models (Gowen et al. 1989, Findlay \& Watling 1994, Cromey et al. 2002), improvements in the digestibility of feed (Cheshuk et al. 2003, Islam 2005, Reid et al. 2008), and waste feed pellet detection (Reid et al. 2008). Integrated Multi-Trophic Aquaculture (IMTA) is another potential approach to minimizing aquaculture impacts (Chopin et al. 2001, Troell et al. 2003). IMTA has been utilized for centuries in Asian countries (Li 1987, Liao 1992, Chiang 1993, Qian et al. 1996) and has recently been developed at the commercial level in Canada (Soto 2009). IMTA involves cultivating several species from different trophic levels in a manner that allows one species' waste feed and/or by-products to be utilized by other species in the system and converted into an extracted resource. Optimizing the desired synergistic interactions between the various crop species requires an advanced understanding of aquaculture-ecosystem dynamics.

Several countries have investigated the integration of filter-feeding bivalve species (e.g. mussels, scallops and oysters) at fish farms to intercept and bioaccumulate particulate organic wastes (Soto 2009), even though they may also contribute to local benthic organic enrichment through faeces production (Cranford et al. 2013). Bivalves cultivated inside and close to some open-water fish farms have been observed to grow significantly faster than animals held at control sites (Jones \& Iwama 1991, Stirling \&
Okumus 1995, Lander et al. 2004, Sarà et al. 2009, Handå et al. 2012, Lander et al. 2012, Jiang et al. 2013), suggesting an enrichment of the natural seston diet with organic fish wastes. However, other studies indicate no significant influence on bivalve growth (Taylor et al. 1992, Cheshuk et al. 2003, Navarrete-Mier et al. 2010). The difference in findings may indicate the importance of local environmental factors that control particulate waste dispersion, which need to be considered in IMTA system design. Ideally, the organic extractive species should be placed at locations that maximize exposure to the suspended particulate matter plume exiting the fish cages (Reid et al. 2008). The hypothesis of a waste plume typically infers that at some location surrounding the farm, total suspended particulate matter (TPM) will be enhanced and transported away from the farm by tidal currents while being diluted mainly by dispersion. Whether or not this conceptual suspended particle plume exists at fish aquaculture sites has yet to be determined.

The objective of the present study was to quantify the effect of open-water Atlantic salmon and sablefish aquaculture on the spatial dynamics of the suspended particle field surrounding the net-pens. Additional data collected on temporal variations in suspended particle concentrations at the study sites will be presented elsewhere. A high-resolution 3-D spatial survey approach was employed in this study using in situ particle sensors to characterize both natural spatial variations in the seston and the distribution of particulate fish wastes.

\section{MATERIALS AND METHODS}

\section{Study sites and sampling strategy}

Investigations of Atlantic salmon aquaculture effects on suspended particles were conducted at 3 separate IMTA farms in the macrotidal Quoddy region of the Bay of Fundy, eastern Canada (other species on site included mussels and kelp). The Navy Island site (Passamaquoddy Bay; $45^{\circ} 01.85^{\prime} \mathrm{N}$, $67^{\circ} 00.16^{\prime} \mathrm{W}$ ) contained 15 circular floating collar netpens. The Charlie Cove farm (Back Bay; $45^{\circ} 01.85^{\prime} \mathrm{N}$, $66^{\circ} 52.00^{\prime} \mathrm{W}$ ) had 8 pens and the Man-O-War farm (Bliss Harbour; $45^{\circ} 02.13^{\prime} \mathrm{N}, 66^{\circ} 50.57^{\prime} \mathrm{W}$ ) contained 16 pens (Fig. 1). All sites contained fish in their final season of growth and automated feeding was underway during sampling periods. Actual fish stocking levels are not reported by industry, but each salmon cage is known to contain between 30000 to 

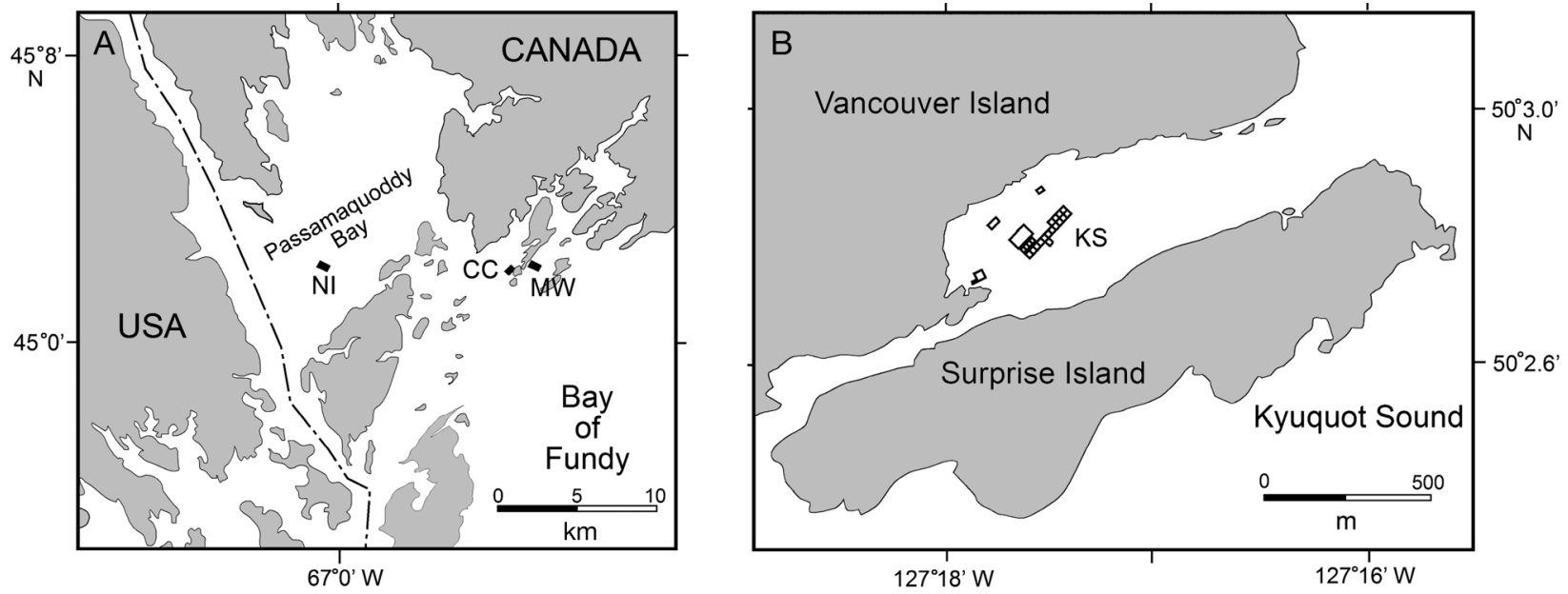

Fig. 1. Location of study sites in (A) the Bay of Fundy, New Brunswick (Atlantic salmon farms), and (B) near Vancouver Island in British Columbia (sablefish farm). The Navy Island (NI), Charlie Cove (CC), Man-O-War (MW) and Kyuquot Sound (KS) fish farms are indicated by the rectangles

50000 fish, giving a minimum of 450000,240000 and 480000 fish under culture at the Navy Island (NI), Charlie Cove (CC) and Man-O-War (MW) farms, respectively. The floating net-pens were $15 \mathrm{~m}$ in depth and the NI and CC sites were $23 \mathrm{~m}$ in depth while the MW site averaged $14 \mathrm{~m}$ depth. Other salmon farms in the region were located between $550 \mathrm{~m}$ (MW site) to several $\mathrm{km}$ (NI and CC sites) away from the study sites. Tides at the Bay of Fundy sites were semidiurnal with an average tidal range of $7 \mathrm{~m}$.

The sablefish IMTA farm was in the mesotidal area of Kyuquot Sound (KS) on the northwest coast of Vancouver Island, western Canada (Fig. 1; 50 2' $\left.48.52^{\prime \prime} \mathrm{N}, 127^{\circ} 17^{\prime} 45.87^{\prime \prime} \mathrm{W}\right)$. Two square steel frame net-pens contained approx. 100000 fish of harvest size during this study, and other pens contained small quantities of scallops and kelp. Fish were manually fed prior to the sampling periods. Water depth at the KS farm is approx. $28 \mathrm{~m}$ and subject to a $3 \mathrm{~m}$ average semi-diurnal tidal range.

The overall study design consisted of biophysical instrument surveys conducted across a range of spatial scales (water depth and sampling distance to netpens) that may be relevant to the distribution of fish wastes. First, instrument profiling was conducted inside a sablefish cage during feeding to address the hypothesis that fine waste particles are produced from feed pellets (referred to as feed fines) and, if so, to determine the depth of particle enhancement. Second, geospatial surveys were conducted with a towed vehicle capable of rapidly collecting information on particle concentrations in the upper water column (up to $10 \mathrm{~m}$ depth), both inside and outside the farm boundaries. This approach was selected, instead of a control-impact experimental design, to avoid assumptions regarding waste transport direction and dispersion, and natural particle distributions. These synoptic surveys were designed to address the hypothesis of the existence of a particulate waste plume exiting net-pens in surface waters (e.g. feed fines). Third, transect surveys were conducted to provide greater depth coverage (surface to $25 \mathrm{~m}$ ), to further increase sampling effort immediately adjacent to the net-pens, and to increase the potential for detecting larger waste particles (i.e. fish faeces) that may exit the net-pens below the depth of the towed vehicle surveys.

\section{Particle-sensing instrumentation}

Two particle sensor platforms were used in this study depending on the spatial sampling approach employed (2-D transect profiling or 3-D spatial mapping). 3-D suspended particulate matter surveys were conducted using an Acrobat LTV-50 computercontrolled undulating vehicle (Sea Sciences). The Acrobat sensor payload consisted of a CTD (AML Oceanographic MicroCTD), a chlorophyll a ( $\mathrm{chl}$ a) fluorometer (Seapoint Sensors) and a transmissometer with a $25 \mathrm{~cm}$ optical path length (c-Rover CRV5, WET Labs) for measuring TPM concentrations. For each survey, the Acrobat was towed at approx. $2 \mathrm{~m}$ $\mathrm{s}^{-1}$ while continuously undulating between set depths. The instruments were powered from the surface by $12 \mathrm{~V}$ batteries and all measurements were made at a sampling frequency of $1 \mathrm{~Hz}$. The sensor data stream was combined in real-time with simultaneous GPS 
readings using Windmill 7 data acquisition and visualization software (Windmill Software). The Acrobat surveys were designed to consider the possibility of relatively near-field (inside and between net-pen arrays) and far-field (5 $\mathrm{m}$ to approx. $500 \mathrm{~m}$ from the farm boundaries) effects of the farms on particle concentrations (see Fig. 2). Regions within the survey domain that were up-current from the farm and orthogonal to the flow direction are considered to represent natural (reference) conditions.

A second sensor platform called the WASP consisted of the same sensor payload taken from the Acrobat, with the exception of a Cyclops chl a fluorometer (Turner Designs) instead of the Seapoint fluorometer. The WASP frame was designed to be compact and light for manual profiling operations. The sensors were encased inside a streamlined polyethylene jacket that allowed water to flow past the instruments while preventing instrument entanglement with mooring ropes. The WASP was continuously lowered and raised between $0.5 \mathrm{~m}$ and up to $25 \mathrm{~m}$ depth while the boat moved slowly along sampling transects (i.e. 2-D surveys). Transects were selected to be perpendicular to the current direction and were located at different distances from the farms (see Fig. 3). All WASP sensor data were georeferenced in real-time during data acquisition.

\section{Data acquisition}

Sensor surveys inside farm boundaries (i.e. nearfield surveys) were conducted at the KS sablefish and MW salmon farms. Sampling in the center of a KS net-pen was conducted on 28 July 2011 using the WASP profiler. Profiling between 1 and $15 \mathrm{~m}$ depth was repeated continually before, during and after manual feeding operations (total sampling time of $50 \mathrm{~min}$ ). Sampling at the MW site was conducted on 10 September 2009 by towing the Acrobat between the net-pens. Owing to rope placements, Acrobat undulations were set between 1 and $4 \mathrm{~m}$ depth and the survey was conducted from 12:57 to 14:54 h (all times are local).

Far-field surveys (outside farm boundaries) were conducted at the NI and CC salmon farms and at the KS sablefish farm. All fieldwork at the NI site was conducted in 2010. An Acrobat survey was performed on 16 June, while WASP transect surveys were performed on 16 and 30 November, and on 1 December. Data acquisition at the CC site was conducted in the summer of 2011. Acrobat surveys were performed on 5 and 6 July, and a WASP transect was surveyed on 7 July. An Acrobat survey of the KS farm was conducted on 26 July 2011. The sampling trajectories of the far-field Acrobat surveys are summarized in Fig. 2. Surveys at the NI and KS farms were conducted between depth intervals of $0.5-10 \mathrm{~m}$ while the CC site was surveyed between 0.5 and $5 \mathrm{~m}$ depth. Inner boundaries of each survey were determined by farm structures (buoys, ropes and vessels), while outer boundaries were either determined by the surrounding coastal morphology or the capacity to complete the full survey in less than approx. $2 \mathrm{~h}$. This time limitation was decided based on a compromise between the desire to collect far-field data and the possibility that longer surveys can be affected by temporal variations in TPM resulting from natural tidal periodicity.

Transect sampling surveys were conducted on 4 separate occasions ( 3 surveys at NI and 1 at CC) using the WASP (Fig. 3). These were performed on opposing sides of each farm across the prevailing current direction, on ebb and flood tides, and at various distances from the center of each farm. One survey focused on measuring particles entering the farm on consecutive ebb and flood tides (Fig. 3B) to examine tidal cycle differences in natural seston conditions.

Current meters were deployed during several surveys. An Argonault-ADV (SonTek/YSI) was deployed at $5 \mathrm{~m}$ depth during the 16 November 2010 WASP survey at the NI farm and an Infinity-EM current meter (JFE Advantec), moored at $1.8 \mathrm{~m}$ depth, provided current information during surveys of the CC farm. The Infinity current meter was moored at $18 \mathrm{~m}$ depth at the KS farm during sampling operations. The locations of the current meter moorings are shown in Figs. 2 \& 3.

\section{Instrument calibration}

In situ calibration of the Seapoint fluorometer was conducted using seawater samples collected beside the Acrobat with a 21 Kemmerer sampler. Water samples stored in pre-rinsed 11 Nalgene bottles were filtered through pre-washed GC-50 filters (Advantec, $25 \mathrm{~mm}$ glass fibre) and kept frozen $\left(-20^{\circ} \mathrm{C}\right)$ in the dark until analysis. The chl a content of particles collected on the filters was determined by the fluorometric technique of Holm-Hansen et al. (1965). The Cyclops fluorometer was also calibrated under field conditions by comparing water column vertical profiles obtained with both the Cyclops and a previously field-calibrated WETStar fluorometer (Wet Labs). 

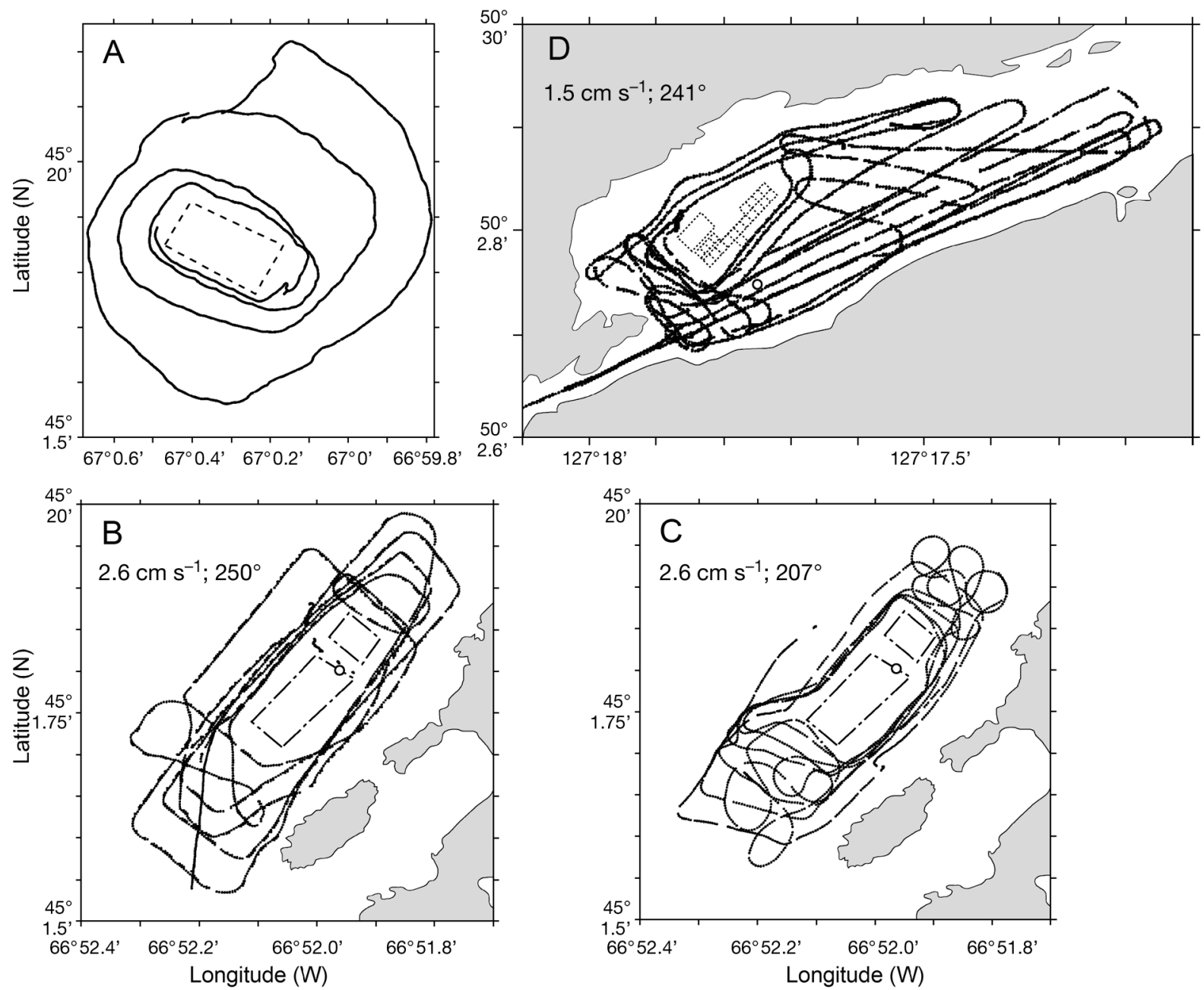

Fig. 2. Acrobat tow tracks (sampling points) outside farm boundaries at (A) Navy Island on 16 June 2010, (B) Charlie Cove on 5 July 2011, (C) Charlie Cove on 6 July 2011 and (D) Kyuquot Sound on 26 July 2011. Gaps in the tow path are due to the removal of data $>0.5 \mathrm{~m}$ depth (see 'Data analysis'). Farm boundaries are depicted by dashed/dotted lines. Average current speed and the prevailing direction over the survey period are provided, when available, and the current meter location is shown as open circles

Regression analysis of measured chl a $\left(\mu \mathrm{g} \mathrm{l} \mathrm{l}^{-1}\right)$ versus fluorescence voltage $(\mathrm{mV})$ for the Seapoint and Cyclops instruments provided the following relationships; chl $a=5.007 \times($ Seapoint $\mathrm{mV})+0.970\left(\mathrm{r}^{2}=0.93\right.$, $\mathrm{n}=46)$ and chl $\mathrm{a}=6.435 \times($ Cyclops $\mathrm{mV})+0.033\left(\mathrm{r}^{2}=\right.$ $0.89, \mathrm{n}=443)$, respectively.

The Acrobat and WASP surveys used the same cRover transmissometer for estimating TPM concentration $\left(\mathrm{mg} \mathrm{l}^{-1}\right)$. In situ calibration was conducted using water samples collected in triplicate at the same depth as the cRover and stored in the same manner described above. Water samples were filtered through pre-rinsed and pre-weighed GC-50 filters (Advantec, $25 \mathrm{~mm}$ ) and rinsed with ammonium formate to remove salt. Filters were then dried at $60^{\circ} \mathrm{C}$ and weighed to determine TPM concentration $\left(\mathrm{mg} \mathrm{l}^{-1}\right.$ ). Percent transmittance $(T)$ for each TPM sample was calculated by dividing the sample read- ing by the zero reading $(3.96 \mathrm{mV}$ for filtered seawater) and multiplying by 100 . Beam attenuation $\left(C_{\mathrm{p}}\right)$ was then calculated using the equation:

$$
C_{\mathrm{p}}=\ln (1 / T) / L
$$

where $L$ is the instrument path length $(0.25 \mathrm{~m})$. Additional laboratory calibrations of the cRover were conducted using 2 standard series prepared from: (1) dry silt and clay particles obtained from the surface (1-10 cm depth) of a core sample collected in the Passamaquoddy Bay, and (2) ground fish feed pellets. Both particle sources were pre-screened through a $160 \mu \mathrm{m}$ mesh and suspended in filtered seawater. The results of TPM gravimetric analysis $\left(\mathrm{mg} \mathrm{l}^{-1}\right)$ for the field and lab samples were compared to instrument $C_{\mathrm{p}}$ measurements using regression analysis. The linear relationship between TPM and $C_{\mathrm{p}}$ was similar for all particle sources, albeit with higher vari- 

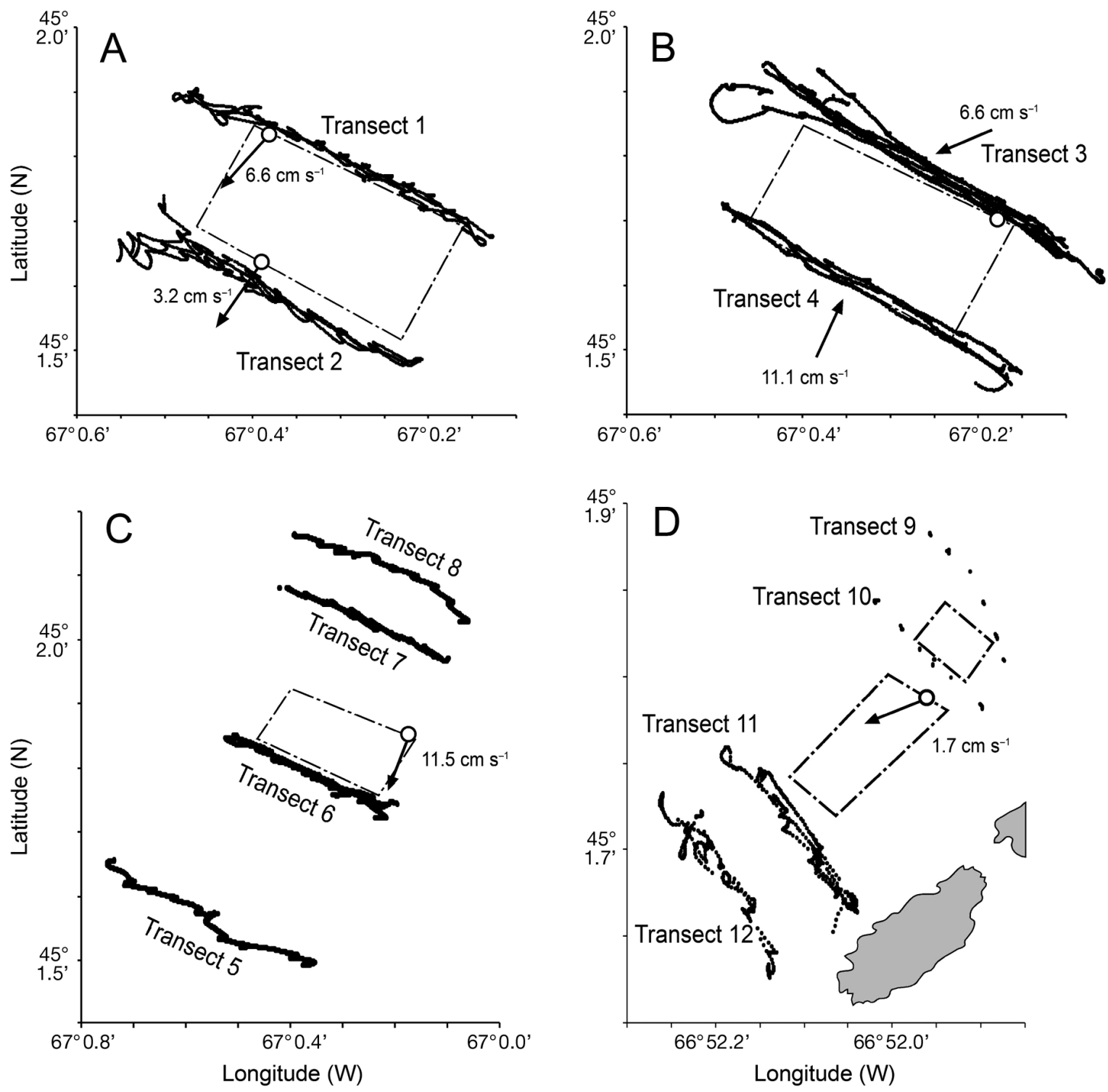

Fig. 3. Sampling locations along the WASP vertical profiling transects at (A) the Navy Island salmon farm on 16 November 2010, (B) 30 November 2010, and (C) 1 December 2010, and at (D) the Charlie Cove farm on 7 July 2011 . Transects 3 and 4 were sampled on ebb and flood tide, respectively. Dot/dash lines depict farm boundaries. The average current speed is given for each sampling period and the prevailing direction is indicated by arrows. Current meter locations are shown as open circles

ability for the field calibration $\left(\mathrm{r}^{2}=0.85, \mathrm{n}=101\right)$ compared with the silt/clay $\left(\mathrm{r}^{2}=0.99, \mathrm{n}=37\right)$ and ground feed $\left(\mathrm{r}^{2}=0.99, \mathrm{n}=16\right)$ standards. The in situ calibration equation $(\mathrm{TPM}=-11.86 \times \ln$ (cRover $\mathrm{mV}$ ) $+17.883)$ was subsequently used to estimate TPM concentrations from the cRover voltage output $(\mathrm{mV})$.

\section{Data analysis}

Data collected during all instrument surveys were initially processed to remove measurements taken above $0.5 \mathrm{~m}$ depth and any gross outliers. The sur- face data was removed to exclude periods when the instruments were at, or above, the surface, and also to exclude air bubble effects on TPM measurements from waves and boat propellers. The outlier data amounted to just a few points per survey $(<0.02 \%$ of data collected) that likely resulted from interference from large macroflora detritus.

Vertical profile plots of chl $a$ and TPM and horizontal contour maps of TPM concentrations were used to summarize and observe spatial patterns in each of the Acrobat survey data sets. Contouring was conducted using ordinary Kriging to produce an interpolated grid based on a logarithmic model (Surfer 9, 
Golden Software). Vertical variability in TPM can confound interpretation of contour maps, so profile plots of the full survey data set were initially examined to ensure limited vertical TPM variability prior to contouring. Interpretation of contour plots can be subjective, particularly where adjacent tow tracks have greatest separation. Therefore, to further investigate the possibility of farm-derived enhancement of TPM, the survey data were subdivided into several geographic areas (boxes) so that regional differences in average TPM concentration could be statistically compared relative to the distance to the farm and the current direction. Geographic swaths through the center of the farm and on either side of the farm were selected to be of equal latitude and longitude range and oriented in the direction of the predominant ebb/flood tide. Data within each swath were then subdivided into boxes (regions) representing different distances from the center of the box to the center of the farm. Distances of each box to the farm were calculated from geographic coordinates (Michels 1997) and classified as either up-current or downcurrent based on the predominant current direction measured during the survey. ArcView 10 GIS software (ESRI) was used to extract TPM measurements from each regional box for comparison.

Vertical profile data collected with the WASP instrument package along each survey transect was divided into 4 depth ranges: $0.5-5 \mathrm{~m}, 5-10 \mathrm{~m}$, 10-15 m, and 15-20 m. Quantitative differences between transects within each of these depth layers was tested separately by 1-way ANOVA (SPSS ver.17) with Transect as the fixed factor. Prior to analysis, transect variances were assessed for homogeneity (Levene's test). Within-treatment normality was not assessed given the robustness of ANOVAs to non-normal distributions (Underwood 1981, Cheshuk et al. 2003). Heterogeneous variances were indicated for all surveys and multiple transformations failed to stabilize these variances. Therefore, the hypothesis of no spatial (transect) effect on the mean TPM concentration was assessed using Welch's ANOVA. As is common with highresolution spatial surveys, significant autocorrelations within the survey data showed that the TPM measurements were spatially dependent (detected using Systat ver.10). The undulating sampling approach between 2 set depths also resulted in a persistent autocorrelation cycle with distance between measurements. Consequently, correction approaches, such as estimating the effective sample size (numbers), would not be able to remedy this problem (Dale \& Fortin 2009). A simple solution that accounts for spatial autocorrelation and provides some assurance that any significant results detected are indeed significant is to adjust $\alpha$ to a lower value (Dale \& Zbigniewicz 1997, Dale \& Fortin 2002). Given the very large sample numbers obtained in this study, reducing $\alpha$ to the highly conservative value of 0.005 will have little impact on the statistical power of the ANOVA to detect a small effect size. In cases of a significant ANOVA result for a site having more than 2 transects, post-hoc tests were used to further explore differences between transect means (Games-Howell test for unequal variances).

\section{RESULTS}

\section{Within-farm sampling}

The results of vertical profiling operations within a net-pen at the KS sablefish farm are summarized in Fig. 4. The vertical TPM concentration profiles conducted before, during and after manual fish feeding are generally similar, except for a small $\left(<0.2 \mathrm{mg} \mathrm{l}^{-1}\right)$ increase in average TPM levels in surface waters (approximately 1 to $3 \mathrm{~m}$ ) during the post-feeding period (Fig. 4). Chl a levels within this same layer

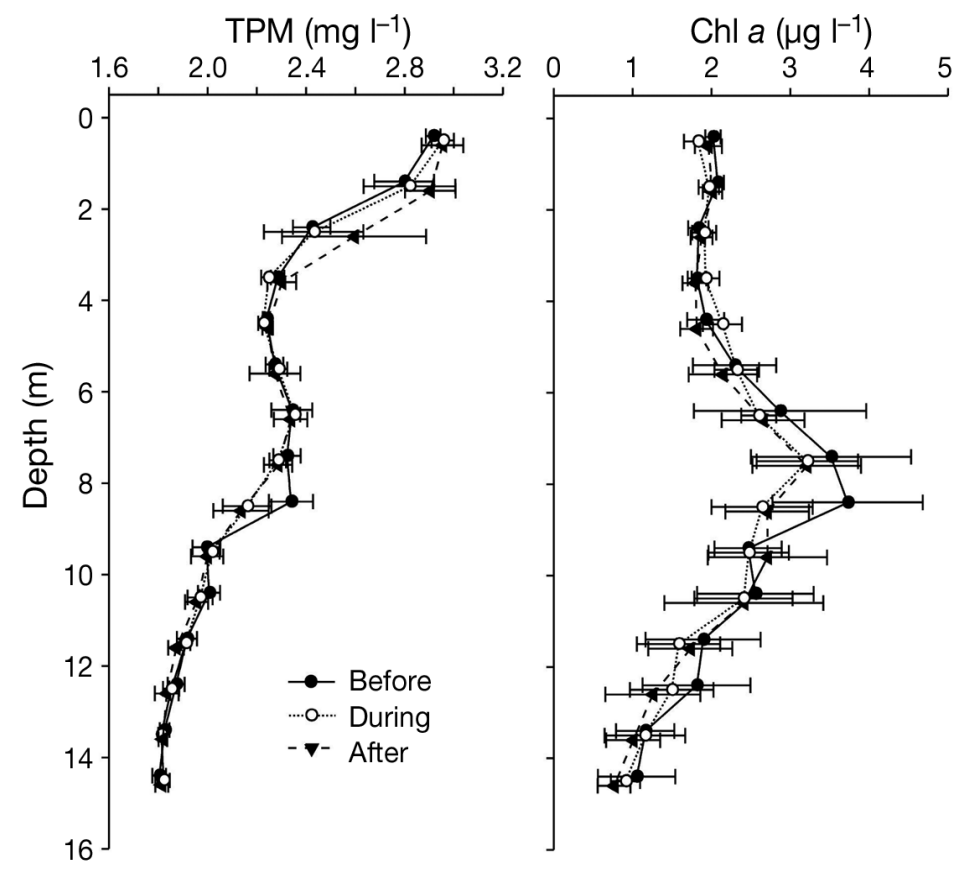

Fig. 4. Depth profile plots of total suspended particulate matter (TPM) and chlorophyll a ( $\mathrm{chl} \mathrm{a)} \mathrm{concentrations} \mathrm{measured} \mathrm{on} 28$ July 2011 inside the Kyuquot Sound sablefish net-pen before, during and after manual feeding of fish. Average $( \pm 1$ SD) values for $1 \mathrm{~m}$ depth intervals are shown 
remained constant during the full sampling period, but varied slightly with time in the vicinity of the chl a maximum (6-9 $\mathrm{m}$ depth). The elevated mean TPM level detected between 8 and $9 \mathrm{~m}$ depth correspond with similar changes in chl a (Fig. 4).

The contour plot of particle concentrations in surface waters (1-4 m depth) within the boundaries of the MW salmon farm showed a largely homogenous distribution of TPM (survey average \pm SD: $1.40 \pm$ $0.05 \mathrm{mg} \mathrm{l}^{-1}$ ), except for lower concentrations (approx. $10-15 \%$ lower compared with adjacent area) detected in the vicinity of each of the 2 circular flotation collars used to support blue mussel culture (Fig. 5).

\section{Far-field surveys}

Vertical profiles of TPM and chl a concentrations measured throughout the surveyed area of the NI and CC salmon farms, and the KS sablefish farm are shown in Fig. 6. TPM concentrations at all 3 sites were predominantly in the range of $2-5 \mathrm{mg} \mathrm{l}^{-1}$. Highest concentrations at the 2 Bay of Fundy sites were mainly confined to the upper $2 \mathrm{~m}$ of the water column (Fig. 6). At these sites, at least $98 \%$ of the TPM values were $\leq 11 \mathrm{mg} \mathrm{l}^{-1}$, and there was little variation in TPM below $2 \mathrm{~m}$ depth (Fig. 6). TPM values at the KS site

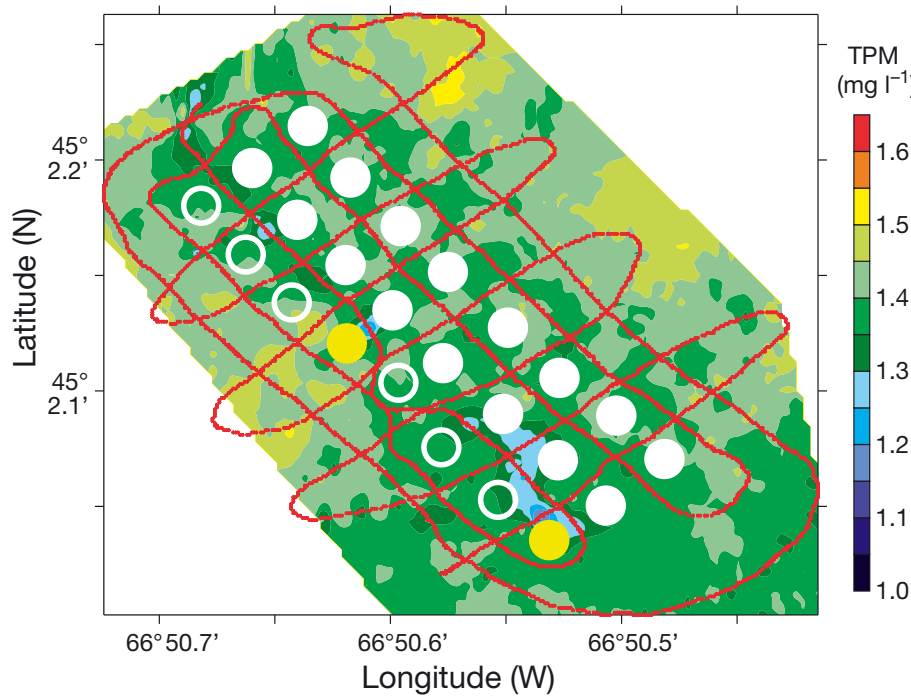

Fig. 5. Colour-scaled contour plots of total suspended particulate matter (TPM; $\mathrm{mg} \mathrm{l}^{-1}$ ) within the 1-5 m depth interval at the Man-O-War salmon farm on 10 September 2009 from 13:00 (low slack tide) to 14:50 h (early flood) GMT. Sampling locations along the Acrobat tow track are shown as lines of red dots $(n=14003)$. White circles indicate the locations of full and empty salmon net-pens (solid white circle for pens containing fish) and yellow circles locate the 2 pens used for mussel culture. The observed surface water flow ranged from north to northeast were also highest near the surface but with elevated TPM levels also occasionally observed in the vicinity of the chl a maximum. Chl a concentrations at NI, CC and KS were generally lowest near the surface, although some elevated values were observed in surface waters at CC (Fig. 6). Given that TPM levels were generally highest in surface waters (i.e. possibly enhanced by fish waste products), geospatial analysis of the Acrobat tow vehicle data focused on the $0.5-2.0 \mathrm{~m}$ depth range.

Contour maps of TPM concentrations within the upper $2 \mathrm{~m}$ of the water column at CC on 5 and 6 July 2011 show that the elevated TPM levels observed in the surface layer (Fig. 6) were distributed in patches in all directions around the farm (Fig. 7). A contour plot is not shown for the Navy Island survey on 16 June 2010 due to the relatively large distance between some tow tracks (Fig. 2A) that may result in excessive data extrapolation. The Acrobat survey of the geographically confined region around the Kyuquot farm was the most extensive conducted during this study (Fig. 2D). Kriging interpolation of all data collected within in the $0.5-8 \mathrm{~m}$ depth range showed patchy TPM concentrations in the survey region with no evidence of a plume of enhanced TPM exiting the farm (Fig. 7C).

The hypothesis of elevated down-current TPM concentrations in surface water (0.5-2 $\mathrm{m}$ depth) relative to the NI and CC salmon farms was further examined by dividing the Acrobat survey data into selected geographic regions and comparing average TPM levels between regions. The NI site survey did not reveal any apparent directional or distance trends in TPM levels, relative to the farm location (Fig. 8). All reference areas (up-current and orthogonal to the flow) exhibited similar mean TPM levels as measured in the down-current regions, with the exception of one down-current (outflow) region that contained a relatively high mean TPM concentration $\left(\sim 1 \mathrm{mg} \mathrm{l}^{-1}\right.$ higher) compared to the reference site (Fig. 8A). For both the 5 and 6 July 2011 surveys at CC, average TPM levels measured approx. $200 \mathrm{~m}$ down-current of the center of this farm tended to be slightly higher $\left(<0.5 \mathrm{mg} \mathrm{l}^{-1}\right.$ enhancement) and more variable than those measured in the reference areas (Fig. 8B,C).

\section{Transect surveys}

The WASP profiling platform permitted data acquisition at greater depths than was possible with the Acrobat tow vehicle, but with reduced spatial resolution. Transect surveys conducted orthogonal to the 

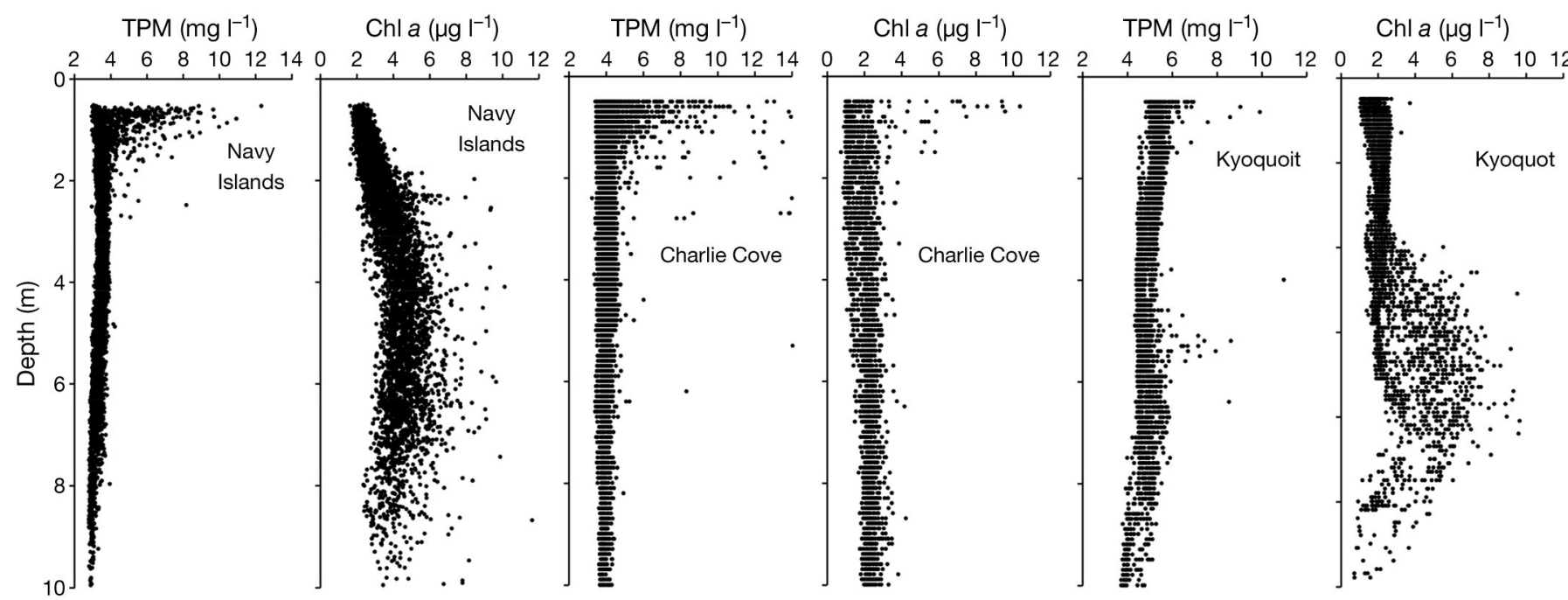

Fig. 6. Depth profile plots of total suspended particulate matter (TPM; mg l-1) and chlorophyll $a$ (chl $a_{i} \mu g l^{-1}$ ) concentrations measured at the Navy Island salmon farm on 16 June $2010(\mathrm{n}=5252)$, at the Charlie Cove salmon farm between 5 and 7 July 2011 ( $\mathrm{n}=13690)$, and at the Kyuquot Sound sablefish farm on 26 July 2011 ( $\mathrm{n}=6082)$
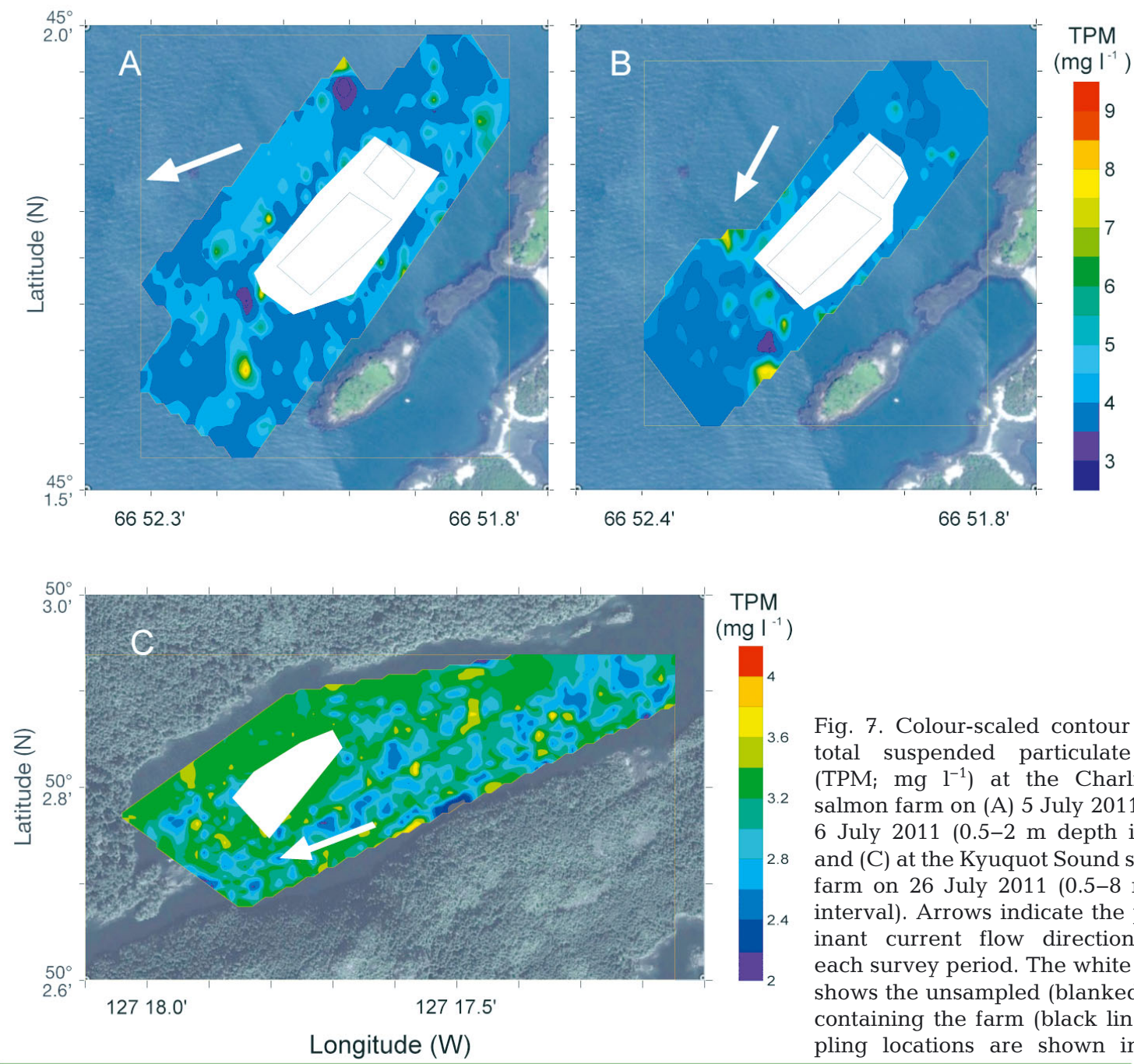

Fig. 7. Colour-scaled contour plots of total suspended particulate matter $\left(\mathrm{TPM}_{i} \mathrm{mg} \mathrm{l}^{-1}\right.$ ) at the Charlie Cove salmon farm on (A) 5 July 2011 and (B) 6 July 2011 (0.5-2 m depth interval), and (C) at the Kyuquot Sound sable fish farm on 26 July 2011 (0.5-8 m depth interval). Arrows indicate the predominant current flow direction during each survey period. The white polygon shows the unsampled (blanked) region containing the farm (black line). Sampling locations are shown in Fig. 2 

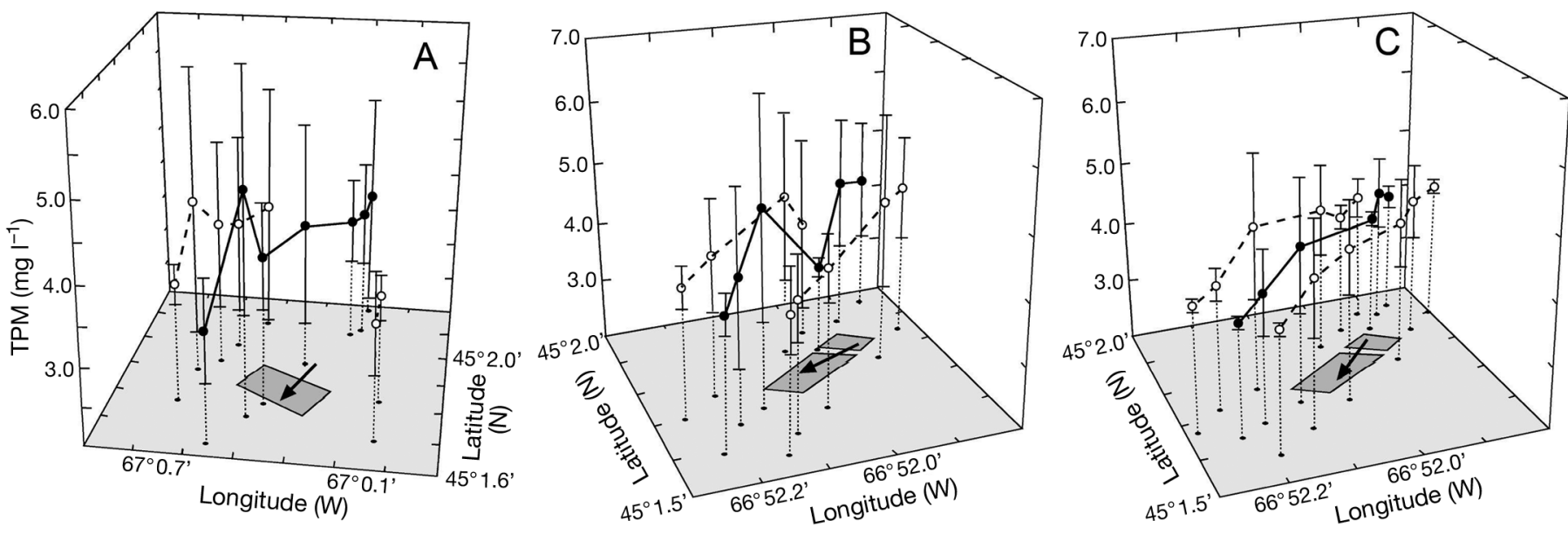

Fig. 8. Total suspended particulate matter concentrations (TPM; $\mathrm{mg} \mathrm{l}^{-1}$ ) averaged within the $0.5-2 \mathrm{~m}$ depth range for selected geographic regions located along transects through the farm (closed circles and solid lines) and on either side (open circles and dashed lines). The transects were oriented along the prevailing current direction (indicated by arrows) and data from each region were extracted from Acrobat surveys of (A) the Navy Island farm on 16 June 2010, (B) the Charlie Cove farm on 5 July 2011 and (C) the Charlie Cove farm on 6 July 2011. The dotted vertical lines show the location of the center of each geographic region relative to the farm location (shaded boxes). Values are means $\pm 1 \mathrm{SD}$

flow direction at different distances to the farm provided snapshots of water properties flowing into and out of the farm. The results of 1-way Welch ANOVA comparisons of mean TPM levels within different depth intervals between selected survey transects (Fig. 3) are given in Tables 1-3. For the NI farm, the largest mean difference in TPM between the inflow and outflow sides of the farm occurred in the $0.5-5 \mathrm{~m}$ depth range on both sampling dates (Table 1). On 16 November, the surface layer on the outflow side of the farm (Transect 2) contained significantly more (average of $1 \mathrm{mg} \mathrm{l}^{-1}$ ) TPM relative to average levels entering the inflow side (Transect 1) (Table 1). The comparison between transects on 30 November detected a significant differences in TPM levels flowing into the farm from the inshore side (Transect 3) than from the offshore (Transect 4) direction (Table 1). Mean TPM difference between transects at deeper depths were small on both dates $\left(<0.2 \mathrm{mg} \mathrm{l}^{-1}\right)$ with significant differences between transects for the 15-20 m depth interval detected on both dates (Table 1). Possible TPM enhancement from the farm only occurred on 30 November. On 16 November, higher concentrations of TPM were detected on the inflow side of the farm (Table 1).

Welch test results for transect surveys conducted on 1 December 2010 at NI (Fig. 3C) and 7 July 2011 at CC (Fig. 3D) indicate significant differences between transects within most of the depth ranges (Tables $2 \& 3$; p < 0.001 for all comparisons except within the $0.5-5 \mathrm{~m}$ depth layer on 7 July at CC). In all comparisons, the mean difference between transects was $<1.5 \mathrm{mg} \mathrm{l}^{-1}$ with only small mean differences in TPM $(<0.4 \mathrm{mg}$ $\mathrm{l}^{-1}$ ) calculated for depths $>5 \mathrm{~m}$. Significant differences were generally unrelated to flow directionality from the farm, highlighting the natural patchy nature of TPM surrounding these sites. For example, posthoc tests from NI on 1 December 2010 indicated that both transects on the inflow side of the farm (Transects 5 and 6) were significantly different in the

Table 1. Welch ANOVA test results of mean concentrations of total suspended particulate matter $\left(\mathrm{mg} \mathrm{l}^{-1}\right)$ between sampling transects at the Navy Island salmon farm on 16 and 30 November 2010. The location of each transect (T1 to T4) is shown in Fig. 3A,B and ANOVA comparisons are for the indicated transects and depth ranges. * Significant at $\alpha=0.005$

\begin{tabular}{|c|c|c|c|c|c|}
\hline $\begin{array}{l}\text { Depth } \\
\text { interval } \\
(\mathrm{m})\end{array}$ & Hypothesis & df & $F$ & $\mathrm{p}$ & $\begin{array}{c}\text { Mean } \\
\text { difference } \\
\left(\mathrm{mg} \mathrm{l}^{-1}\right)\end{array}$ \\
\hline \multicolumn{6}{|c|}{ Navy Island - 16 November 2010} \\
\hline $0.5-5$ & $\mathrm{~T} 1=\mathrm{T} 2$ & 1,1332 & 12.914 & $<0.001^{*}$ & -0.960 \\
\hline $5-10$ & $\mathrm{~T} 1=\mathrm{T} 2$ & 1,675 & 3.121 & 0.078 & 0.006 \\
\hline $10-15$ & $\mathrm{~T} 1=\mathrm{T} 2$ & 1,713 & 3.658 & 0.056 & 0.035 \\
\hline $15-20$ & $\mathrm{~T} 1=\mathrm{T} 2$ & 1,697 & 112.53 & $<0.001^{*}$ & 0.091 \\
\hline \multicolumn{6}{|c|}{ Navy Island - 30 November 2010} \\
\hline $0.5-5$ & $\mathrm{~T} 3=\mathrm{T} 4$ & 1,755 & 20.453 & $<0.001^{*}$ & -0.844 \\
\hline $5-10$ & $\mathrm{~T} 3=\mathrm{T} 4$ & 1,675 & 0.212 & 0.645 & -0.019 \\
\hline $10-15$ & $\mathrm{~T} 3=\mathrm{T} 4$ & 1,556 & 5.724 & 0.017 & -0.199 \\
\hline $15-20$ & $\mathrm{~T} 3=\mathrm{T} 4$ & 1,1283 & 23.078 & $<0.001^{*}$ & -0.051 \\
\hline
\end{tabular}


Table 2. Welch ANOVA and post-hoc test results of mean concentrations of total suspended particulate matter $\left(\mathrm{mg} \mathrm{l}^{-1}\right)$ between sampling transects at the Navy Island salmon farm on 1 December 2010. The location of each transect (T5 to T8) is shown in Fig. 3C and ANOVA comparisons are for the indicated transects and depth ranges. ${ }^{*}$ Significant at $\alpha=0.005$

\begin{tabular}{|c|c|c|c|c|c|c|c|}
\hline \multirow{2}{*}{$\begin{array}{l}\text { Depth } \\
\text { interval } \\
(\mathrm{m})\end{array}$} & \multicolumn{4}{|c|}{ Welch test (all transects) } & \multicolumn{3}{|c|}{ Post-hoc transect comparisons } \\
\hline & Hypothesis & df & $F$ & $\mathrm{p}$ & $\begin{array}{c}\text { Mean } \\
\text { difference } \\
\left(\mathrm{mg} \mathrm{l}^{-1}\right)\end{array}$ & $\mathrm{SE}$ & $\mathrm{p}$ \\
\hline \multirow[t]{7}{*}{$0.5-5$} & $\mathrm{~T} 5=\mathrm{T} 6=\mathrm{T} 7=\mathrm{T} 8$ & 3,628 & 13.737 & $<0.001^{*}$ & & & \\
\hline & $\mathrm{T} 5=\mathrm{T} 6$ & & & & 1.11 & 0.226 & $<0.001^{*}$ \\
\hline & $\mathrm{T} 5=\mathrm{T} 7$ & & & & 1.45 & 0.231 & $<0.001^{*}$ \\
\hline & $\mathrm{T} 5=\mathrm{T} 8$ & & & & 1.37 & 0.254 & $<0.001^{*}$ \\
\hline & $\mathrm{T} 6=\mathrm{T} 7$ & & & & 0.33 & 0.137 & 0.072 \\
\hline & $\mathrm{T} 6=\mathrm{T} 8$ & & & & 0.26 & 0.172 & 0.429 \\
\hline & $\mathrm{T} 7=\mathrm{T} 8$ & & & & -0.07 & 0.179 & 0.978 \\
\hline \multirow[t]{7}{*}{$5-10$} & $\mathrm{~T} 5=\mathrm{T} 6=\mathrm{T} 7=\mathrm{T} 8$ & 3,335 & 7.779 & $<0.001^{*}$ & & & \\
\hline & $\mathrm{T} 5=\mathrm{T} 6$ & & & & 0.025 & 0.005 & $<0.001^{*}$ \\
\hline & $\mathrm{T} 5=\mathrm{T} 7$ & & & & -0.09 & 0.092 & 0.749 \\
\hline & $\mathrm{T} 5=\mathrm{T} 8$ & & & & 0.003 & 0.005 & 0.965 \\
\hline & $\mathrm{T} 6=\mathrm{T} 7$ & & & & -0.117 & 0.092 & 0.548 \\
\hline & $\mathrm{T} 6=\mathrm{T} 8$ & & & & -0.022 & 0.006 & $0.004^{*}$ \\
\hline & $\mathrm{T} 7=\mathrm{T} 8$ & & & & 0.09 & 0.09 & 0.733 \\
\hline \multirow[t]{7}{*}{$10-15$} & $\mathrm{~T} 5=\mathrm{T} 6=\mathrm{T} 7=\mathrm{T} 8$ & 3,286 & 20.809 & $<0.001^{*}$ & & & \\
\hline & $\mathrm{T} 5=\mathrm{T} 6$ & & & & 0.047 & 0.007 & $<0.001^{*}$ \\
\hline & $\mathrm{T} 5=\mathrm{T} 7$ & & & & 0.031 & 0.008 & $0.001^{*}$ \\
\hline & $\mathrm{T} 5=\mathrm{T} 8$ & & & & 0.016 & 0.009 & 0.315 \\
\hline & $\mathrm{T} 6=\mathrm{T} 7$ & & & & -0.016 & 0.004 & $<0.001^{*}$ \\
\hline & $\mathrm{T} 6=\mathrm{T} 8$ & & & & -0.031 & 0.006 & $<0.001^{*}$ \\
\hline & $\mathrm{T} 7=\mathrm{T} 8$ & & & & -0.015 & 0.007 & 0.131 \\
\hline \multirow[t]{7}{*}{$15-20$} & $\mathrm{~T} 5=\mathrm{T} 6=\mathrm{T} 7=\mathrm{T} 8$ & 3,734 & 79.623 & $<0.001^{*}$ & & & \\
\hline & $\mathrm{T} 5=\mathrm{T} 6$ & & & & 0.072 & 0.009 & $<0.001^{*}$ \\
\hline & $\mathrm{T} 5=\mathrm{T} 7$ & & & & 0.048 & 0.009 & $<0.001^{*}$ \\
\hline & $\mathrm{T} 5=\mathrm{T} 8$ & & & & -0.099 & 0.013 & $<0.001^{*}$ \\
\hline & $\mathrm{T} 6=\mathrm{T} 7$ & & & & -0.024 & 0.007 & $0.004^{*}$ \\
\hline & $\mathrm{T} 6=\mathrm{T} 8$ & & & & -0.171 & 0.012 & $<0.001^{*}$ \\
\hline & $\mathrm{T} 7=\mathrm{T} 8$ & & & & -0.147 & 0.012 & $<0.001^{*}$ \\
\hline
\end{tabular}

enhancement during a period when natural seston levels were relatively low and homogeneous (Fig. 5). Particle reductions around mussel lines within this farm was observed (Fig. 5), indicating approx. $10-15 \%$ depletion of food particles by mussels. Transect sampling close to the NI and C salmon farms showed that significant increases in TPM levels occasionally occurred in the surface layer, with a mean effect of $<1.5 \mathrm{mg} \mathrm{l}^{-1}$ (Tables 1-3). Intensive far-field surveys around the KS sablefish farm provided no evidence of the presence of particulate fish wastes (Fig. 7C), but surveys around the NI and CC salmon farms indicated that these farms may have caused a small increase in mean TPM $(<1.0 \mathrm{mg}$ $\mathrm{l}^{-1}$ mean effect) and increased TPM variability on the outflow side of the net-pens (Fig. 8).

If a fish farm has the potential to significantly enhance the particulate matter in the near-field environment, it may be expected that the area 'down-current' of the farm would experience increased TPM concentrations due to tidal advection. One of the more noteworthy findings of this study was the significantly higher

$0.5-5 \mathrm{~m}$ depth range (Table 2). Transect 5 was $22.6 \%$ higher in TPM than Transect 6.

\section{DISCUSSION}

The production of particulate wastes at the openwater fish farms studied resulted in periodic, lowlevel suspended particle matter enhancement (mean effect on TPM $\left.<1.5 \mathrm{mg} \mathrm{l}^{-1}\right)$ in surface waters $(0.5-3 \mathrm{~m}$ depth) within and immediately adjacent to the netpens. The within-pen studies at the KS sablefish farm suggested that fine particulate matter was released at 1-3 m depth during feeding, although this apparent enhancement of TPM was within the range of natural variation prior to feeding (Fig. 4). Within-farm sampling (between net-pens) at the MW salmon farm in the Bay of Fundy did not detect any apparent TPM
TPM in the surface layer along Transect 2 at the NI farm on 16 November 2010 (Fig. 3A, Table 1). The current meter record showed that this transect was sampled during a period when water was flowing from the direction of the farm. The close location of Transect 2 to the farm boundaries left little room for dilution to occur before being detected during sampling. This was the strongest evidence of a potential farm-derived particulate waste 'pulse' throughout this investigation, albeit a small one $\left(<1.0 \mathrm{mg} \mathrm{l}^{-1}\right.$; Table 1$)$.

Troell \& Norberg (1998) calculated that farm waste production could increase suspended solid concentrations anywhere from 3- to 30-fold. Potential farmderived particulate matter would include uneaten whole feed pellets, feed 'fines' and faecal wastes, as reviewed in the 'Introduction'. Early estimates of feed loss were approx. $20 \%$ (Beveridge 1987), but have since been reduced through improved waste 
Table 3. Welch ANOVA and post-hoc test results of mean concentrations of total particulate matter $\left(\mathrm{mg} \mathrm{l}^{-1}\right)$ between sampling transects at the Charlie Cove salmon farm on 7 July, 2011. The location of each transect (T9 to T12) is shown in Fig. 3D, and ANOVA comparisons are for the indicated transects and depth ranges. ${ }^{*}$ Significant at $\alpha=0.005$

\begin{tabular}{|c|c|c|c|c|c|c|c|}
\hline \multirow{2}{*}{$\begin{array}{l}\text { Depth } \\
\text { interva } \\
(\mathrm{m})\end{array}$} & \multicolumn{4}{|c|}{ Welch test (all transects) } & \multicolumn{3}{|c|}{ Post-hoc transect comparisons } \\
\hline & al Hypothesis & df & $F$ & $\mathrm{p}$ & $\begin{array}{c}\text { Mean } \\
\text { difference } \\
\left(\mathrm{mg} \mathrm{l}^{-1}\right)\end{array}$ & $\mathrm{SE}$ & $\mathrm{p}$ \\
\hline $0.5-5$ & $\mathrm{~T} 9=\mathrm{T} 10=\mathrm{T} 11=\mathrm{T} 12$ & 3,124 & 3.507 & 0.017 & & & \\
\hline & $\mathrm{T} 9=\mathrm{T} 10$ & & & & 0.854 & & \\
\hline & $\mathrm{T} 9=\mathrm{T} 11$ & & & & 1.433 & & \\
\hline & $\mathrm{T} 9=\mathrm{T} 12$ & & & & 1.210 & & \\
\hline & $\mathrm{T} 10=\mathrm{T} 11$ & & & & 0.579 & & \\
\hline & $\mathrm{T} 10=\mathrm{T} 12$ & & & & 0.355 & & \\
\hline & $\mathrm{T} 11=\mathrm{T} 12$ & & & & -0.224 & & \\
\hline $5-10$ & $\mathrm{~T} 9=\mathrm{T} 10=\mathrm{T} 11=\mathrm{T} 12$ & 3,155 & 21.725 & $<0.001^{*}$ & & & \\
\hline & $\mathrm{T} 9=\mathrm{T} 10$ & & & & 0.182 & 0.041 & $<0.001^{*}$ \\
\hline & $\mathrm{T} 9=\mathrm{T} 11$ & & & & 0.284 & 0.037 & $<0.001^{*}$ \\
\hline & $\mathrm{T} 9=\mathrm{T} 12$ & & & & 0.206 & 0.039 & $<0.001^{*}$ \\
\hline & $\mathrm{T} 10=\mathrm{T} 11$ & & & & 0.102 & 0.028 & $0.002^{*}$ \\
\hline & $\mathrm{T} 10=\mathrm{T} 12$ & & & & 0.024 & 0.031 & 0.861 \\
\hline & $\mathrm{T} 11=\mathrm{T} 12$ & & & & -0.077 & 0.024 & $0.009^{*}$ \\
\hline $10-157$ & $\mathrm{~T} 9=\mathrm{T} 10=\mathrm{T} 11=\mathrm{T} 12$ & 3,152 & 19.575 & $<0.001^{*}$ & & & \\
\hline & $\mathrm{T} 9=\mathrm{T} 10$ & & & & 0.092 & 0.051 & 0.286 \\
\hline & $\mathrm{T} 9=\mathrm{T} 11$ & & & & 0.213 & 0.045 & $<0.001^{*}$ \\
\hline & $\mathrm{T} 9=\mathrm{T} 12$ & & & & 0.140 & 0.046 & 0.016 \\
\hline & $\mathrm{T} 10=\mathrm{T} 11$ & & & & 0.122 & 0.027 & $<0.001^{*}$ \\
\hline & $\mathrm{T} 10=\mathrm{T} 12$ & & & & 0.048 & 0.028 & 0.306 \\
\hline & $\mathrm{T} 11=\mathrm{T} 12$ & & & & -0.073 & 0.013 & $<0.001^{*}$ \\
\hline $15-207$ & $\mathrm{~T} 9=\mathrm{T} 10=\mathrm{T} 11=\mathrm{T} 12$ & 3,151 & 26.018 & $<0.001^{*}$ & & & \\
\hline & $\mathrm{T} 9=\mathrm{T} 10$ & & & & 0.115 & 0.071 & 0.379 \\
\hline & $\mathrm{T} 9=\mathrm{T} 11$ & & & & 0.326 & 0.065 & $<0.001^{*}$ \\
\hline & $\mathrm{T} 9=\mathrm{T} 12$ & & & & 0.321 & 0.065 & $<0.001^{*}$ \\
\hline & $\mathrm{T} 10=\mathrm{T} 11$ & & & & 0.212 & 0.029 & $<0.001^{*}$ \\
\hline & $\mathrm{T} 10=\mathrm{T} 12$ & & & & 0.206 & 0.028 & $<0.001^{*}$ \\
\hline & $\mathrm{T} 11=\mathrm{T} 12$ & & & & -0.005 & 0.005 & 0.735 \\
\hline
\end{tabular}

degradation and water turbulence (Ismond 1993, Summerfelt 1999, Brinker \& Rösch 2005). Biodegradation may be heightened within a net-pen fish farm due to the activities of biofouling biota such as microbes. Turbulence is of particular importance in particle transport and dispersion. Localized turbulence is generated by the fish and cage structure, and a high degree of regional diffusivity occurs naturally in the tidally energetic Bay of Fundy. Although the past focus on particle dynamics at fish farms has been on sedimentation processes (Brown et al. 1987, Gowen \& Bradbury 1987, Gowen et al. 1988, Wildish et al. 1990, Findlay et al. 1995, Brooks et al. 2002), a source of smaller particles suspended in the upper water column may exist. However, the present study provided only limited evidence to support this theory.

Elevated levels of particulate matter in surface waters around fish net-pens may reflect farmderived enhancement and/or natural detrital and inorganic matter variability. Previous studies investigating fish culture-phytoplankton interactions and the pellet detection and feeding control mechanisms (Reid et al. 2008). Feed wastage is now routinely $<5 \%$ (Cromey et al. 2002, Perez et al. 2002, Strain \& Hargrave 2005, Stucchi et al. 2005). There are many possible mechanisms by which fish feed fines can be produced at a fish farm. The use of automated feeding methods can create a dusty by-product (Cheshuk et al. 2003, Kullman et al. 2009, Reid et al. 2010), and this feeding method was employed at the Bay of Fundy study sites. It has also been suggested that some faecal material may exit a net-pen system as fine particulate matter rather than as whole pellets, due to factors such as the high digestibility of fish feed, possible changes to the feed binders and aggressive fish swimming activity (Troell \& Norberg 1998). Furthermore, even larger suspended waste particles are expected to become smaller over time by way of natural destructive forces, such as bio- time-scales involved for phytoplankton turnover indicate that enhanced primary production in the vicinity of an open-water fish farm is an unlikely cause of seston enhancement (Gowen et al. 1988, Wildish et al. 1993, Stirling \& Okumus 1995, Cheshuk et al. 2003). Relatively high TPM levels in surface waters at the study sites were not associated with relatively high chl a levels (Fig. 6) and are therefore not the result of phytoplankton enhancement from dissolved nutrient fish wastes. Although MacDonald et al. (2011) reported that salmon farm sites in Passamaquoddy Bay exhibited significantly higher TPM levels than measured $200 \mathrm{~m}$ from the farms, it is difficult to attribute any of the elevated TPM concentrations observed in the present study solely to a farm-based source of waste particulate matter. The towed vehicle and transect sampling surveys revealed a high degree of natural patchiness in TPM concentrations at the study sites 
(Figs. 5-8; Tables 1-3), and a potential farm impact of $<1.5 \mathrm{mg} \mathrm{l}^{-1}$ is within the range of natural variability. TPM concentrations were occasionally highest on the inflow side of a farm (Figs. $7 \& 8$ ) and natural seston conditions varied on ebb and flood tide (Table 1). Natural TPM variability at the studied fish farms (Fig. 7) may therefore explain the occasional presence of higher TPM levels close to the fish farms. Similar results were found by Cheshuk et al. (2003) where the level of enrichment was not outside the natural range, supporting the argument that waste production from these farms is likely too low and/or too easily dispersed to significantly elevate food concentrations.

The results of the present study are not meant to suggest that waste particulates are not produced at the study sites. The lack of a strong and consistent signal of suspended TPM enhancement surrounding the fish farms likely highlights a much stronger downward flux component to the particulate waste stream. This vertical particle flux is prominent in aquaculture waste dispersal models such as DEPOMOD (Cromey et al. 2002). Processes such as turbulence, reduced flow due to baffling by net structures, and bio-fouling may also foster an environment that increases the aggregation and vertical flux of fine suspended solids. Periods of higher turbulence, such as that generated by fish activity alone, have been thought to increase the chance of collisions between particles, leading to increased flocculation. This is especially true for organic particles and in areas where microbial biomass is high, as may be the case surrounding these sites. The production of extracellular polymers and polysaccharides by microbes strongly favours the adhesion of smaller particles to form larger ones (Brinker \& Rösch 2005). Milligan \& Law (2005) showed that the introduction of waste feed, faecal material, and their resulting degradation products from open-cage coastal aquaculture operations has the potential to increase particle stickiness. In fact, divers have reported that particles large enough to be viewed by the naked eye can be seen attached to net-pen structures, indicating that they are sticky in nature (S. M. C. Robinson pers. obs.). Consequently, this flocculation can increase the deposition of particulate matter (Milligan \& Law 2005). For these reasons, it is to be expected that the majority of the waste particulate matter would be rapidly transported vertically and therefore would not remain suspended near the surface of the water column.

The overall production scale and fish behaviour are of importance when considering the extent of impact a fish farm has on the surrounding particle field. With the exception of the possible presence of within-cage
TPM enhancement from fish feed fines inside the KS sablefish net-pen during feeding (Fig. 4), there was no indication that this farm impacted the surrounding suspended particle field. Greater indications of seston enhancement at the Bay of Fundy salmon farms could be due in part to large differences in fish stocking densities, volume of food added, the overall production scale between these farms, and fish behaviour. Sablefish primarily remain near the bottom of the net-pens except during feeding. Defaecation primarily at the base of the net-pen would reduce waste inputs to surface waters, relative to salmon culture. The larger scale farming activities at the Bay of Fundy salmon sites mean substantially more feed delivery and waste production than at the KS farm. Brinker \& Rösch (2005) showed that higher fish biomass can significantly reduce waste particle size due to factors such as increased turbulent swimming activity, and consequently generates a larger amount of smaller particles that remain suspended in the surface layer.

Results reported herein on the near- and far-field distribution of suspended particles do not support the concept of the presence of a 'waste plume'. Cheshuk et al. (2003) concluded that wastes from cages are dispersed in all directions due to cyclic shifts in current flow. The fish net-pens are porous and highly flexible; characteristics which can strongly govern the flow pattern both within and around the fish farm (Løland 1993). The influence of farm structure, and any other farms nearby, in conjunction with fish behaviour and other daily farm activities, fosters an environment of highly complex flow patterns that will govern the trajectory and behaviour of fish waste streams. While it might be expected that currents driven by the $7 \mathrm{~m}$ tidal range at the Bay of Fundy study sites would control the transport of suspended fish wastes in a strongly advective manner, dispersive processes within fish farms should not be underestimated and may prevent the formation of a confined waste discharge plume. Results presented on the large spatial variability in natural seston concentrations and the periodic nature of fish waste particle enhancement highlights the reality of an intricate hydrodynamic system and complex natural suspended particle field. These dynamics preclude the presence of a slowly dispersing plume of waste particles uniformly radiating away from open-water aquaculture sites. Troell \& Norberg (1998) referred to an 'enriched pulse' of wastes as more likely than a continuously present plume due to the nature of periodic feeding and probable mass release of faeces at some time after feeding. 
When considering the design and feasibility of an efficient (i.e. food production and waste recycling) IMTA system, it is important to understand both the production and accessibility of fish waste streams. All the study sites selected for this study are commercial IMTA farms, with mussels (Mytilus edulis, Bay of Fundy farms) and scallops (Patinopecten yessoensis, KS farm) cultured as the particulate fish waste extractive component. In both cases, the majority of bivalves are cultured in surface waters to aid in the recycling and extraction of fine particulate organic wastes. The strongest farm-derived signal detected in this investigation, albeit only intermittent, was immediately adjacent to the fish cages. It has been suggested that under low-to-moderate current conditions, bivalves would need to be cultured well within $50 \mathrm{~m}$ of the fish cages (Cheshuk et al. 2003). This conclusion is in agreement with previous studies examining the co-culture of finfish and bivalves (Brown et al. 1987, Gowen \& Bradbury 1987, Coyne et al. 1994, Findlay et al. 1995, Cheshuk et al. 2003, Lander et al. 2012) that showed the limited horizontal displacement of increased seston levels away from the farm. This limited zone of occasional food enhancement significantly restricts the area for bivalve coculture that would enhance their growth relative to monoculture.

Acknowledgements. This work was supported by the Department of Fisheries and Oceans Canada and the Natural Sciences and Engineering Research Council of Canada through contributions to the strategic Canadian Integrated Multi-Trophic Aquaculture Network (CIMTAN). The authors thank Drs. Steve Cross, Paul Hill and Mike Dowd for their many contributions, advice and assistance throughout this project.

\section{LITERATURE CITED}

Beveridge MCM (1987). Cage aquaculture. Fishing news books, Surrey

Brinker A, Rösch R (2005) Factors determining the size of suspended solids in a flow-through fish farm. Aquacult Eng 33:1-19

Brooks KM, Mahnken C, Nash C (2002) Environmental effects associated with marine netpen waste with emphasis on salmon farming in the Pacific Northwest. In: Stickney RR, McVey JP (eds) Responsible marine aquaculture. CABI Publishing, Wallingford, p 159-203

$>$ Brown JR, Gowen RJ, McLusky DS (1987) The effect of salmon farming on the benthos of a Scottish sea loch. J Exp Mar Biol Ecol 109:39-51

$>$ Buschmann A, Troell M, Kautsky N, Kautsky L (1996) Integrated tank cultivation of salmonids and Gracilaria chilensis. Hydrobiologia 326/327:75-84

Cheshuk BW, Purser GJ, Quintana R (2003) Integrated open-water mussel (Mytilus planulatus) and Atlantic salmon (Salmo salar) culture in Tasmania, Australia. Aquaculture 218:357-378

Chiang YM (1993) Seaweed cultivation in Taiwan. In: Liao IC, Cheng JH, Wu MC, Guo JJ (eds) Proceedings of the symposium on aquaculture held in Beijing. Taiwan Fisheries Research Institute, Keelung, p 143-151

Chopin T, Buschmann AH, Halling C, Troell M and others (2001) Integrating seaweeds into marine aquaculture systems: a key towards sustainability. J Phycol 37:975-986

$>$ Coyne R, Hiney M, O'Connor B, Kerry J, Cazabon D, Smith $P$ (1994) Concentration and persistence of oxytetracycline in sediments under a marine salmon farm. Aquaculture 123:31-42

Cranford PJ, Reid GK, Robinson SMC, (2013) Open water integrated multi-trophic aquaculture: constraints on the effectiveness of mussels as an organic extractive component. Aquacult Environ Interact 4:163-171

Cromey CJ, Nickell TD, Black KD (2002) DEPOMOD modeling the deposition and biological effects of waste solids from marine cage farms. Aquaculture 214:211-239

Dale MRT, Fortin MJ (2002) Spatial autocorrelation and statistical tests in ecology. Ecoscience 9:162-167

Dale MRT, Fortin MJ (2009) Spatial autocorrelation and statistical tests: some solutions. J Agricult Biol Environ Stat 14:188-206

Dale MRT, Zbigniewicz MW (1997) Spatial pattern in boreal shrub communities: effects of a peak in herbivore density. Can J Bot 75:1342-1348

FAO (Food and Agriculture Organisation of the United Nations) (2010) Global aquaculture production. FAO, Fisheries and Aquaculture Department, Rome. Available at www.fao.org/fishery/statistics/global-aquacultureproduction/en (accessed 1 June 2012)

Findlay R, Watling B (1994) Toward a process level model to predict the effects of salmon net pen aquaculture. In: Hargrave BT (ed) Modelling benthic impact of organic enrichment from marine aquaculture. Can Tech Rep Fish Aquat Sci 1949. Department of Fisheries and Oceans Canada, Dartmouth, p 47-77

> Findlay RH, Watling L, Mayer LM (1995) Environmental impact of salmon net-pen culture on marine benthic communities in Maine: a case study. Estuaries 18:145-179

Gowen RJ, Bradbury NB (1987) The ecological impact of salmonid farming in coastal waters: a review. Oceanogr Mar Biol Annu Rev 25:563-575

Gowen RJ, Brown J, Bradbury NB, McLusky DS (1988) Investigations into benthic enrichment, hypernutrification and eutrophication associated with mariculture in Scottish coastal waters. J Exp Mar Biol Ecol 109:39-51

Gowen RJ, Bradbury NB, Brown JR (1989) The use of simple models in assessing two of the interactions between fish farming and the marine environment. In: Billard R, de Pauw N (eds) Aquaculture-technology in progress. European Aquaculture Society, Bredene, p 189-199

> Handå A, Min H, Wang X, Broch OJ, Reitan KI, Helge R, Olsen Y (2012) Incorporation of fish feed and growth of blue mussels (Mytilus edulis) in close proximity to salmon (Salmo salar) aquaculture: implications for integrated multi-trophic aquaculture in Norwegian coastal waters. Aquaculture 356-357:328-341

- Holm-Hansen O, Lorenzen CJ, Holmes RW, Strickland JDH (1965) Fluorometric determination of chlorophyll. ICES J Mar 30:3-15

Holmer M, Wildish D, Hargrave B (2005) Organic enrichment from marine finfish aquaculture and effects on sed- 
iment biogeochemical processes. In: Hargrave BT (ed) Environmental effects of marine finfish aquaculture. Springer, Berlin, p 181-206

Islam MS (2005) Nitrogen and phosphorus budget in coastal and marine cage aquaculture and impacts of effluent loading on ecosystem: review and analysis towards model development. Mar Pollut Bull 50:48-61

Ismond AA (1993) Designing fish farms to reduce the costs of environmental compliance. In: Wang JK (ed) Techniques for modern aquaculture. American Society of Agricultural Engineers, Spokane, WA, p 187-192

> Jiang Z, Wang G, Fang J, Mao Y (2013) Growth and food sources of Pacific oyster Crassostrea gigas integrated culture with sea bass Lateolabrax japonicus in Ailian Bay, China. Aquacult Int 21:45-52

Jones TO, Iwama GK (1991) Polyculture of the Pacific oyster, Crassostrea gigas (Thunberg), with Chinook salmon, Oncorhynchus tshawytscha. Aquaculture 92:313-322

Kullman MA, Kidd KA, Podemski CL, Paterson MJ, Blanchfield PJ (2009) Assimilation of freshwater salmonid aquaculture waste by native aquatic biota. Can J Fish Aquat Sci 66:1965-1975

Lander T, Barrington K, Robinson S, MacDonald B, Martin J (2004) Dynamics of the blue mussel as an extractive organism in an integrated aquaculture system. Bull Aquacult Assoc Can 104:19-28

> Lander TR, Robinson SMC, MacDonald BA, Martin JD (2012) Enhanced growth rates and condition index of blue mussels (Mytilus edulis) held at integrated multitrophic aquaculture (IMTA) sites in the Bay of Fundy. J Shellfish Res 31:997-1007

> Lefebvre S, Barille L, Clerc M (2000) Pacific oyster (Crassostrea gigas) feeding responses to a fish-farm effluent. Aquaculture 187:185-198

Li S (1987) Energy structure and efficiency of a typical Chinese integrated fish farm. Aquaculture 65:105-118

Liao IC (1992) Aquaculture in Asia: status, constraints, strategies and prospects. In: Liao IC, Shyu CZ, Chao NH (eds) Aquaculture in Asia: proceedings of the 1990 APO symposium in aquaculture. Taiwan Fisheries Research Institute, Keelung, p 13-27

- Løland G (1993) Current forces on, and water flow through and around, floating fish farms. Aquacult Int 1:72-89

MacDonald BA, Robinson SMC, Barrington KA (2011) Feeding activity of mussels (Mytilus edulis) held in the field at an integrated multi-trophic aquaculture (IMTA) site (Salmo salar) and exposed to fish food in the laboratory. Aquaculture 314:244-251

Mente E, Pierce GJ, Santos MB, Neofitou C (2006) Effect of feed and feeding in the culture of salmonids on the marine aquatic environment: a synthesis for European aquaculture. Aquacult Int 14:499-522

Michels C (1997) Latitude/longitude distance calculation. Available at http://jan.ucc.nau.edu/ cvm/latlongdist.html (accessed 30 January 2012)

Milligan TG, Law BA (2005) The effect of marine aquaculture on fine sediment dynamics in coastal inlets. In: Hargrave BT (ed) Environmental effects of marine finfish aquaculture. Springer, Berlin, p 239-251

- Navarrete-Mier F, Sanz-Lázaro C, Marín A (2010) Does bivalve mollusc polyculture reduce marine fin fish farming environmental impact? Aquaculture 306:101-107

Perez OM, Telfer TC, Beveridge MCM, Ross LG (2002) Geographical information systems (GIS) as a simple tool to aid modeling of particulate waste distribution at marine fish cage sites. Estuar Coast Shelf Sci 54:761-768

Pridmore RD, Rutherford JC (1992) Modelling phytoplankton abundance in a small enclosed bay used for salmon farming. Aquacult Fish Manag 23:525-542

> Qian PY, Wu CY, Wu M, Xie YK (1996) Integrated cultivation of the red alga Kappaphycus alvarezii and the pearl oyster Pinctada martensi. Aquaculture 147:21-35

Reid GK, Liutkus M, Robinson SMC, Chopin TR and others (2008) A review of the biophysical properties of salmonid faeces: implications for aquaculture waste dispersal models and integrated multi-trophic aquaculture. Aquacult Res 40:257-273

Reid GK, Liutkus M, Bennett A, Robinson SMC, MacDonald B, Page F (2010) Absorption efficiency of blue mussels (Mytilus edulis and M. trossulus) feeding on Atlantic salmon (Salmo salar) feed and fecal particulates: implications for integrated multi-trophic aquaculture. Aquaculture 299:165-169

Sarà G, Zenone A, Tomasello A (2009) Growth of Mytilus galloprovincialis (Mollusca bivalvia) close to fish farms: a case of integrated multi-trophic aquaculture in the Tyrrhenian sea. Hydrobiologia 636:129-136

Soto D (2009) Integrated mariculture: a global review. FAO Fish Aquacult Tech Pap 529. FAO, Rome

Stirling HP, Okumus I (1995) Growth and production of mussels (Mytilus edulis L.) suspended at salmon cages and shellfish farms in two Scottish sea lochs. Aquaculture 134:193-210

Strain PM, Hargrave BT (2005) Salmon aquaculture, nutrient fluxes and ecosystem processes in southwestern New Brunswick. In: Hargrave BT (ed) Environmental effects of marine finfish aquaculture. Springer, Berlin, p 29-57

Stucchi D, Sutherland TA, Levings C, Higgs D (2005) Nearfield deposition model for salmon aquaculture waste. In: Hargrave BT (ed) Environmental effects of marine finfish aquaculture. Springer, Berlin, p 157-179

Summerfelt ST (1999). Waste-handling systems. In: Wheaton FW (ed) CIGR handbook of agricultural engineering, Vol 2: animal production \& aquacultural engineering. American Society of Agricultural Engineers, St. Joseph, MD, p 309-350

Taylor BE, Jamieson G, Carefoot TH (1992) Mussel culture in British Columbia: the influence of salmon farms on growth of Mytilus edulis. Aquaculture 108:51-66

Troell M, Norberg J (1998) Modelling output and retention of suspended solids in an integra ted salmon-mussel culture. Ecol Model 110:65-77

> Troell M, Halling C, Neori A, Chopin T, Buschmann AH, Kautsky N, Yarish C (2003) Integrated mariculture: asking the right questions. Aquaculture 226:69-90

Underwood AJ (1981) Techniques of analysis of variance in experimental marine biology and ecology. Oceanogr Mar Biol Annu Rev 19:513-605

Wildish DJ, Zitko V, Akagi HM, Wilson AJ (1990) Sedimentary anoxia caused by salmonid mariculture wastes in the Bay of Fundy and its effects on dissolved oxygen in sea water. In: Saunders RL (ed) Proceedings of CanadaNorway finfish aquaculture workshop, September 11-14, 1989. Can Tech Rep Fish Aquat Sci 1761. Department of Fisheries and Oceans Canada, Biological Station, St. Andrews, p 11-18

Wildish DJ, Keizer PD, Wilson AJ, Martin JL (1993) Seasonal changes of dissolved oxygen and plant nutrients in seawater near net pens in the macrotidal Bay of Fundy. Can J Fish Aquat Sci 50:303-311 